\title{
MENINGKATKAN WAWASAN MAHASISWA PRA-SKRIPSI TENTANG MANAJEMEN REFERENSI OTOMATIS BERBASIS MENDELEY
}

\author{
Itsna Oktaviyanti, Mohammad Archi Maulyda, Lalu Wira Zain Amrullah, Iva \\ Nurmawanti, Muhammad Erfan
}

\author{
Program Studi Pendidikan Guru Sekolah Dasar, FKIP, Universitas Mataram \\ archimaulyda@unram.ac.id
}

\begin{abstract}
This community service aims to solve the problem of writing references and bibliography for students who start writing their thesis. The community service is carried out in several stages, namely preparing webinars, Mendeley-based Automatic Reference Management webinars, and evaluating webinar activities - the Preparation of webinar activities, including coordination, Preparation of zoom accounts, and flyers for students. The Mendeley-based Automatic Reference Management webinar is the community service's core activity. The webinar evaluation is carried out by post-test. The service activities that have been carried out are considered successful shown by actions that have been done. The participants' enthusiasm is relatively high, and the insight into writing references and making student bibliography increases. This evident from the time the webinar activity was according to plan. The webinar participants reached 96 students, and the post-test results showed that students' understanding of automatic reference management had increased by up to $77.5 \%$.
\end{abstract}

Keywords: students, thesis, reference, Mendeley

\begin{abstract}
Abstrak
Tujuan dari kegiatan ini adalah untuk mengatasi masalah penulisan rujukan dan daftar pustaka pada mahasiswa yang akan mulai menulis skripsi. Untuk mencapai tujuan tersebut, maka dilaksanakan pengabdian kepada masyarakat dengan beberapa tahapan yaitu persiapan kegiatan webinar, webinar Manajemen Referensi Otomatis Berbasis Mendeley dan evaluasi kegiatan webinar. Persiapan kegiatan webinar di antaranya koordinasi, persiapan akun zoom dan flyer untuk mahasiswa, kemudian webinar Manajemen Referensi Otomatis Berbasis Mendeley sebagai kegiatan inti pengabdian. Evaluasi webinar dilaksanakan dengan posttest kegiatan webinar. Kegiatan pengabdian yang telah dilaksanakan dirasa berhasil. Keberhasilan ditunjukkan dengan kegiatan yang berjalan dengan lancar, antusiasme peserta yang cukup tinggi serta wawasan menulis rujukan dan membuat daftar pustaka mahasiswa meningkat. Hal tersebut terbukti dari waktu kegiatan webinar sesuai dengan rencana, peserta webinar mencapai 96 mahasiswa dan hasil posttest yang menunjukkan bahwa pemahaman mahasiswa mengenai manajemen referensi otomatis mengalami peningkatan hingga 77,5\%.
\end{abstract}

Kata kunci: mahasiswa, skripsi, referensi, mendeley 


\section{PENDAHULUAN}

Skripsi adalah bentuk tugas akhir yang harus diselesaikan oleh mahasiswa pada jenjang Strata 1 (sarjana). Skripsi merupakan salah satu bentuk dari karya tulis ilmiah yang dalam penulisannya terdapat Batasan dan Rambu-rambu yang harus diikuti (Melfianora, 2019). Menurut Wang \& Blei (2011) dalam penulisan karya tulis ilmiah, struktur penulisan dan diksi tulisan berbeda dengan karya sastra lainya. Secara definisi, karya tulis ilmiah adalah sebuah tulisan hasil buah pikir yang bersifat faktual (bukan fiksi/karangan). Di dalam Skripsi juga harus memuat argumentasi-argumentasi dari para ahli dan penulis itu sendiri.

Perlunya argumentasi dari para ahli adalah; (1) menjadi pijakan bagi penulis/peneliti untuk mengkaji satu topik; (2) menjadi penguat argumentasi peneliti agar tulisan dalam skripsi dapat mengikis unsur opini dan meningkatkan unsur faktual (Benestad, 2015). Pada tahap inilah mahasiswa sering mengalami kesulitan, yakni pada saat menulis rujukan. Sangat penting untuk menulis rujukan dengan benar sesuai dengan aturan. Karena jika terjadi kesalahan pada nama atau pada tahun, ada kemungkinan tulisan tersebut tidak tersitasi. Tentu hal ini akan merugikan penulis atau ahli yang dirujuk, serta secara tidak langsung akan terjadi kegiatan plagiarisme (Bruton \& Childers, 2016).

Dewasa ini, perkembangan teknologi berjalan sangat cepat bahkan seakan mendahului perkembangan manusia itu sendiri (Setiawan, 2017). Tidak terkecuali dibidang penulisan karya ilmiah termasuk skripsi. Adanya kesulitan yang biasanya dialami mahasiswa dalam merujuk, akhirnya melahirkan inovasi berwujud software manajemen referensi otomatis bernama
Mendeley (Hicks, 2011). Software Mendeley lahir pada tahun 2007, dan saat ini sudah terakuisisi oleh Publisher Elsevier (Mohammadi et al., 2016). Kebutuhan akan Software Mendeley ini tidak hanya untuk penulisan skripsi, tapi juga dalam penulisan artikel-artikel ilmiah.

Saat ini tidak sedikit perguruan tinggi di Indonesia yang mewajibkan mahasiswanya untuk memiliki publikasi ilmiah di jurnal-jurnal yang ada (Kadir, 2017). Termasuk di Universitas Mataram, mahasiswa sudah diwajibkan untuk memiliki publikasi artikel di jurnal-jurnal ilmiah. Bahkan pada tahun 2020 ini, publikasi artikel dapat menggugurkan kewajiban mahasiswa untuk melaksanakan seminar hasil sebagai syarat ujian skripsi. Padahal berdasarkan pengamatan yang dilakukan oleh dosen pengampu mata kuliah seminar, kemampuan mahasiswa dalam menulis karya ilmiah, khususnya pada tahap merujuk masih sangat rendah. Selain itu, masalah yang sering muncul pada mahasiswa adalah kesulitan mahasiswa dalam membuat daftar rujukan. Sering terjadi daftar rujukan tidak sesuai dengan rujukanrujukan yang ada dalam isi karya ilmiah. Sehingga tim pengabdian kepada masyarakat (PKM) merasa perlu untuk melaksanakan kegiatan sosialisasi manajemen referensi otomatis berbasis Mendeley untuk mengatasi masalah penulisan rujukan dan daftar pustaka pada mahasiswa yang akan mulai menulis skripsi (Tugas Akhir).

Untuk memastikan kegiatan ini tepat sasaran, tim PKM melakukan pemetaan masalah kepada mahasiswa semester VII Prodi PGSD Universitas Mataram. Tim PKM melakukan survey online lewat google form untuk menggali informasi tentang wawasan awal mahasiswa. Berikut hasil survey awal yang dilakukan kepada mahasiswa 


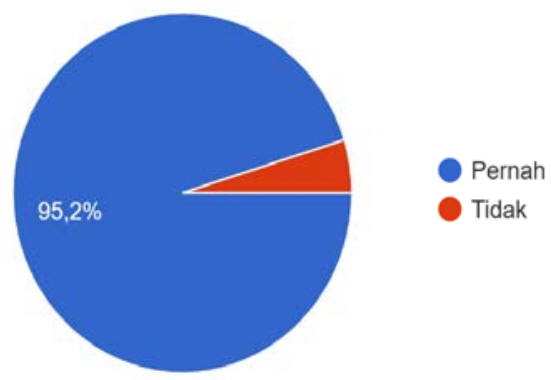

Gambar 1. Jumlah mahasiswa yang kesulitan dalam membuat daftar pustaka

Berdasarkan Gambar 1 dapat diketahui bahwa masih banyak mahasiswa semester VII pada Prodi PGSD Universitas Mataram mengalami kesulitan dalam membuat daftar pustaka. Dari 82 mahasiswa yang mengisi survey $95,2 \%$ atau 80 mahasiswa merasa kesulitan, sedangkan 4 mahasiswa lainya tidak merasa kesulitan dalam membuat daftar pustaka. Hal ini cukup memprihatinkan mengingat mahasiswa semester VII sebentar lagi akan mulai mengerjakan skripsi. Kesulitan dalam membuat daftar pustaka ini akan menjadi hambatan yang cukup besar bagi mahasiswa untuk menyelesaikan tugasnya. Fenomena ini menurut Knight et al. (2010) merupakan salah satu faktor tingginya angka mahasiswa yang tidak dapat menyelesaikan masa studi tepat waktu. Menurut hasil riset Rahardja et al. (2016) faktor penyelesaian tugas akhir lebih mempengaruhi masa studi mahasiswa daripada penyelesaian kewajiban lulus dari mata kuliah pada jenjang perguruan tinggi. Oleh karena itu mahasiswa harus mulai diperkenalkan dengan manajemen referensi otomatis seperti Mendeley untuk mempermudah proses pengerjaan skripsi.

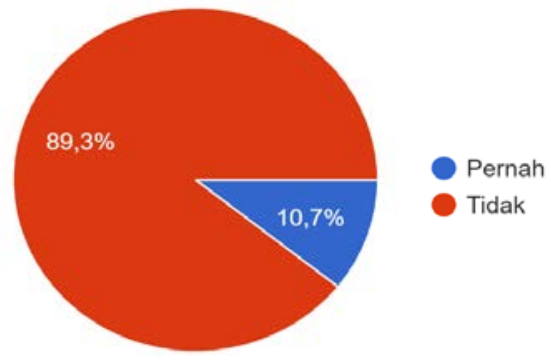

Gambar 2. Jumlah mahasiswa yang pernah mendengar Mendeley

Namun kenyataannya, menurut gambar 2, hanya $10,7 \%$ atau 9 mahasiswa yang pernah mendengar Software Mendeley. Sedangkan 89,3\% atau 75 mahasiswa tidak pernah mendengar software ini. Hal ini menunjukkan bahwa wawasan mahasiswa terkait dengan pembuatan daftar pustaka masih sangat rendah. Hal inilah yang juga menjadi faktor utama dari banyaknya mahasiswa yang mengalami kesulitan dalam membuat daftar pustaka. Padalah menurut Mohammadi et al. (2016) penggunaan Mendeley dalam penulisan karya ilmiah akan sangat membantu ketepatan dan kecepatan seseorang dalam menyelesaikan tulisannya.

Selain itu sedikitnya mahasiswa yang mengetahui software ini juga menunjukkan bahwa selama ini mahasiswa masih membuat daftar pustaka secara manual. Hal ini sangat rawan terjadi pelanggaran kode etik rujukan seperti salah merujuk atau tidak mencantumkan rujukan pada daftar pustaka yang berakibat pada tidak adanya sitasi kepada penulis. Hal ini tentu merugikan penulis yang dirujuk oleh mahasiswa. Menurut Bain et al. (2011) pelanggaran kode etik penulisan ini biasa ditemukan pada mahasiswa yang sedang mengerjakan skripsi. Banyak mahasiswa yang melewatkan rujukannya pada daftar pustaka yang sudah dibuat. 


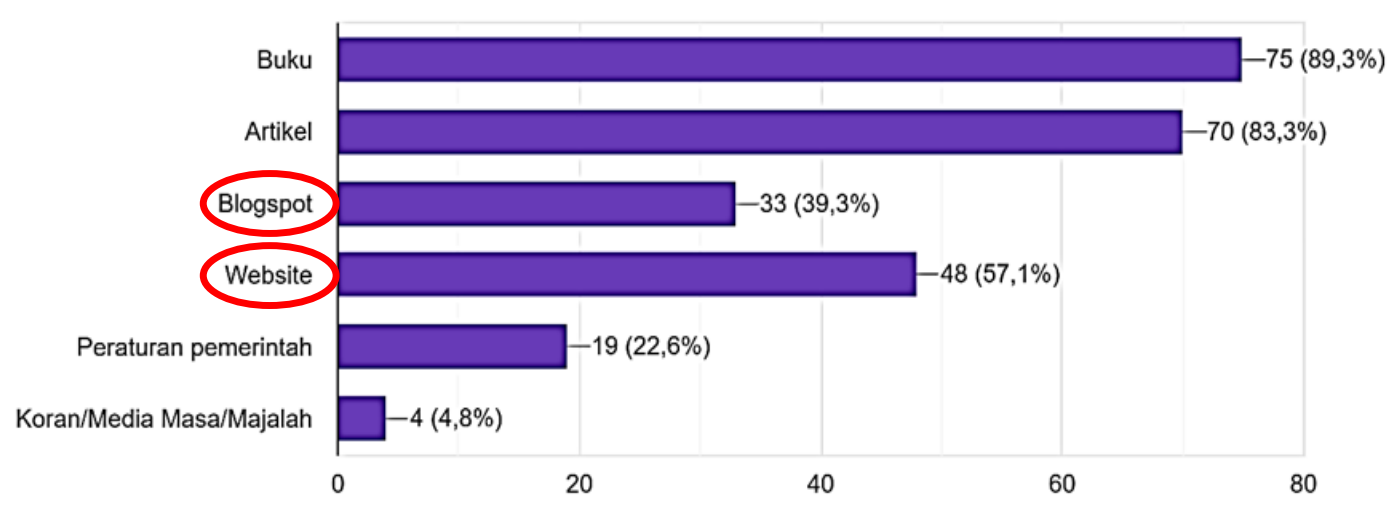

Gambar 3. Jenis rujukan yang sering digunakan mahasiswa

Selain masalah diatas, pada gambar 3 dapat kita lihat bahwa mahasiswa semester VII Prodi PGSD, Universitas Mataram memiliki kemampuan berliterasi yang kurang baik. Hal ini terlihat pada pilihan rujukan yang sering digunakan mahasiswa dalam menulis karya ilmiah. Terdapat 48 mahasiswa yang memilih informasi pada website sebagai bahan rujukannya. Tidak hanya itu, juga terdapat 33 mahasiswa yang memilih blogspot sebagai bahan rujukan dalam tulisannya. Padahal kedua sumber online ini selayaknya tidak dapat digunakan sebagai pijakan untuk menulis sesuatu yang sifatnya faktual (fakta). Baik website maupun blogspot tidak memiliki kurasi yang cukup untuk dikatakan sebagai suatu kebenaran (Rahardja et al., 2016). Selain itu kedua sumber ini juga bersifat sangat subjektif bahkan terkesan opini (Adhiarso et al., 2017). Apabila informasi dalam website dan blogspot yang kebenarannya masih tidak dapat dipertanggungjawabkan ini digunakan sebagai rujukan, maka hasil tulisannya pun tingkat kepercayaannya juga dapat kita pertanyakan.

Berdasarkan paparan di atas, tim PKM Prodi PGSD menemukan beberapa masalah yakni: (1) Masih banyak mahasiswa yang merasa kesulitan dalam membuat daftar pustaka. (2) Masih banyak mahasiswa yang tidak mengetahui software Mendeley sebagai alat untuk membuat daftar pustaka secara otomatis. (3) Masih banyak mahasiswa yang tidak memahami jenis rujukan apa yang sebaiknya digunakan dalam pembuatan karya tulis ilmiah/Skripsi.

\section{METODE}

Untuk menyelesaikan masalah yang ditemukan pada mahasiswa semester VII Prodi PGSD Universitas Mataram, tim PKM membuat rancangan kegiatan seperti pada gambar 4 .
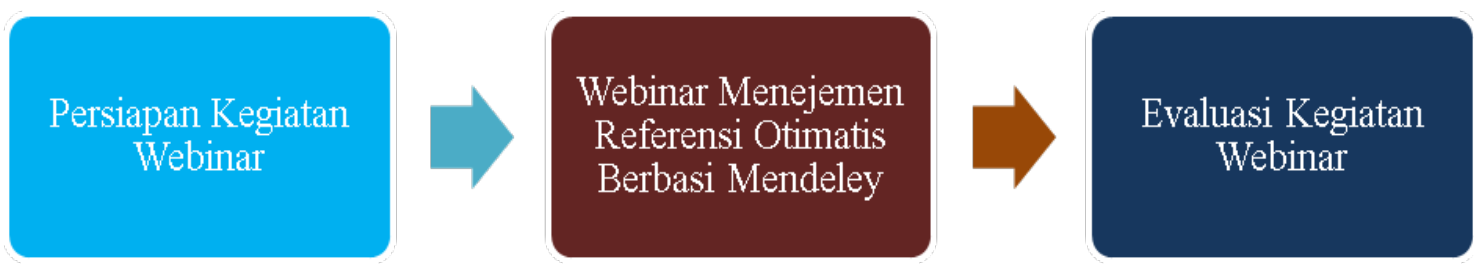

Gambar 4. Rencana Kegiatan Pengabdian 
Itsna Oktaviyanti, dkk. Meningkatkan Wawasan Mahasiswa Pra-Skripsi Tentang....

\section{HASIL DAN PEMBAHASAN}

\section{Persiapan Kegiatan Webinar}

Pada tahap ini, tim menyiapkan segala hal terkait dengan pelaksanaan kegiatan webinar. Kegiatan webinar dipilih mengingat kondisi pandemi COVID-19 yang mengharuskan masyarakat untuk tidak berkumpul dan menjaga jarak (social distancing). Kegiatan webinar yang dilakukan secara online dan diikuti mahasiswa dari masing-masing rumah dirasa cukup tepat. Hal-hal yang dipersiapkan tim antara lain akun zoom meeting dan desain flyer untuk mahasiswa. Berikut desain flyer yang disebarkan kepada mahasiswa:

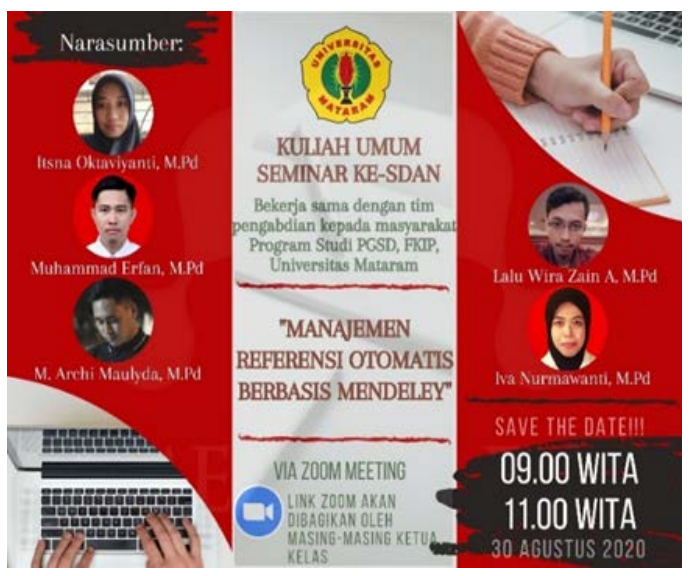

Gambar 5. Desain Flyer Webinar

Selain itu tim juga berkoordinasi dengan koordinator mata kuliah "seminar ke-SDan" yang dari awal menjadi muara ditemukannya masalahmasalah penulisan rujukan dan daftar pustaka ini. Tim PKM membalut kegiatan webinar dalam kuliah umum "seminar ke-SDan" karena melihat adanya keselarasan kegiatan dengan tujuan mata kuliah ini diberikan kepada mahasiswa. Selain itu, dengan adanya integrasi antara tim PKM dengan mata kuliah "seminar ke-SDan" ini akan memudahkan tim PKM untuk mengkoordinasikan peserta ketika pelaksanaan webinar berlangsung.

\section{Pelaksanaan Webinar}

Kegiatan webinar dilaksanakan pada hari minggu, 30 Agustus 2020. Hari minggu dipilih untuk memastikan anggota tim PKM yang rata-rata adalah seorang dosen tidak memiliki jam kuliah dan dapat berpartisipasi dalam kegiatan webinar ini. Dari 6 anggota tim PKM, 5 di antaranya memberikan materi dan 1 dosen menjadi moderator. Materi-materi yang diberikan antara lain; (1) Sejarah \& Perkembangan Mendeley; (2) Manfaat \& Fungsi Mendeley; (3) Instalasi di \& sinkronisasi Mendeley; (4) mencari referensi di jurnal nasinal dan internasional untuk di masukan ke dalam Mendeley; (5) Contoh Menggunakan Mendeley).

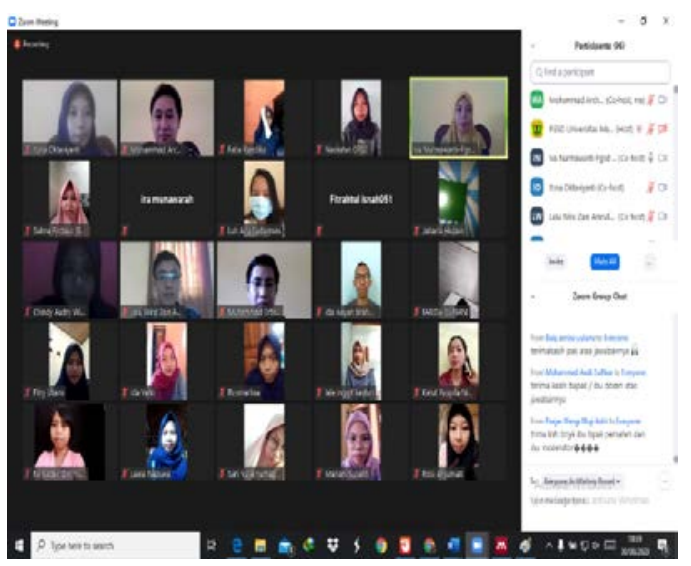

Gambar 6. Dokumentasi Kegiatan Webinar tim PKM

Kegiatan webinar dilaksanakan selama 2 jam, yakni dimulai pada pukul 09.00 WITA sampai pukul 11.00 WITA. Masing-masing materi diberikan waktu 10-20 menit tergantung pada kedalaman materi dan luas tidaknya materi yang diberikan. Kegiatan berjalan lancar dan banyak mahasiswa yang aktif bertanya selama termin pertanyaan dibuka. Total terdapat 6 pertanyaan yang diberikan oleh mahasiswa. Berdasarkan data pada tautan daftar hadir yang diberikan, jumlah total mahasiswa yang mengikuti 
kegiatan ini adalah 96 mahasiswa dengan proporsi 83 mahasiswa semester VII dan 13 mahasiswa semester V.

\section{Evaluasi Kegiatan Webinar}

Kegiatan evaluasi ini dilakukan dengan memberikan tautan postest setelah kegiatan webinar selesai dilaksanakan. Dari 96 mahasiswa yang mengikuti kegiatan, hanya 89 mahasiswa yang mengisi tautan evaluasi ini, berikut hasil evaluasi kegiatan webinar yang dilaksanakan tim PKM:

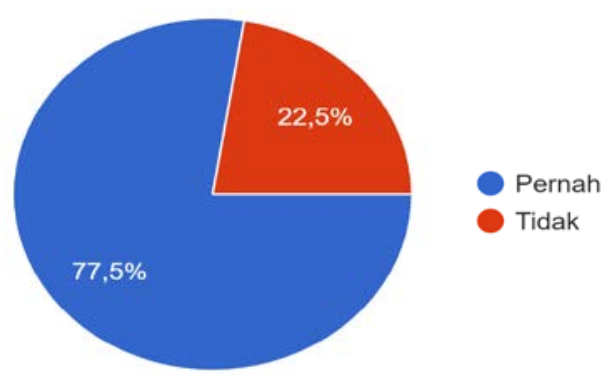

Gambar 7. Mahasiswa yang pernah belajar manajemen referensi otomatis

Berdasarkan gambar 7, terlihat bahwa jumlah mahasiswa yang memahami manajemen referensi otomatis jauh meningkat. Setelah kegiatan jumlah mahasiswa yang memahami manajemen referensi otomatis meningkat menjadi $77,5 \%$ atau 69 mahasiswa, sedangkan 22,5\% atau 20 mahasiswa lainya masih belum terlalu memahami. Hal ini menunjukkan bahwa kegiatan webinar yang dilaksanakan dapat meningkatkan wawasan mahasiswa semester VII Prodi PGSD tentang manajemen referensi otomatis terutama menggunakan software Mendeley.

Selain itu, pada gambar 8 terlihat bahwa mahasiswa mulai memahami jenis rujukan seperti apa yang layak digunakan dalam penulisan skripsi. $68,5 \%$ atau 61 mahasiswa memilih artikel sedangkan $29,2 \%$ atau 26 mahasiswa memilih buku. Hal ini menunjukkan bahwa mahasiswa sudah dapat menentukan rujukan mana yang baik untuk digunakan dalam skripsi mereka.

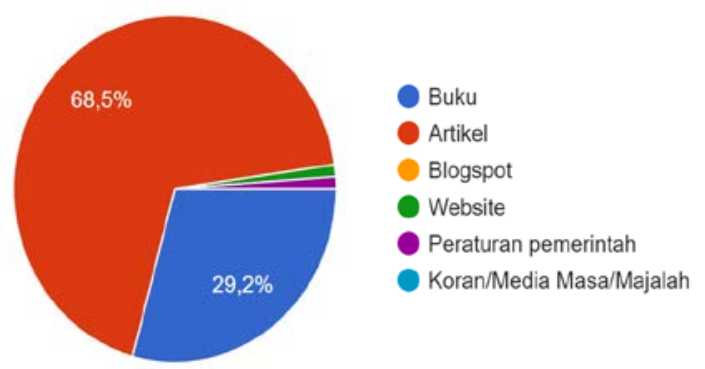

Gambar 8. Rujukan yang paling baik menurut mahasiswa

\section{SIMPULAN}

Berdasarkan hasil evaluasi kegiatan webinar manajemen referensi otomatis berbasis Mendeley yang diberikan kepada mahasiswa pra-skripsi (Semester VII) Prodi PGSD, Universitas Mataram, dapat disimpulkan bahwa Kegiatan berjalan dengan lancar dan sesuai dengan rencana tim PKM, Antusias mahasiswa cukup tinggi melihat jumlah peserta mencapai 96 mahasiswa, dan Kegiatan Webinar ini dapat meningkatkan wawasan menulis rujukan dan membuat daftar pustaka mahasiswa.

\section{UCAPAN TERIMA KASIH}

Penulis mengucapkan terima kasih kepada Universitas Mataram yang telah memberikan bantuan finansial melalui skema PNBP Universitas Mataram Tahun Anggaran 2020.

\section{DAFTAR PUSTAKA}

Adhiarso, D. S., Utari, P., \& Slamet, Y. (2017). Pemberitaan Hoax di Media Online Ditinjau dari Konstruksi Berita dan Respons 
Itsna Oktaviyanti, dkk. Meningkatkan Wawasan Mahasiswa Pra-Skripsi Tentang....

Netizen. Jurnal Ilmu Komunikasi, 4(1), 34-56.

Bain, S., Fedynich, L., \& Knight, M. (2011). The successful graduate student: a review of the factors for success. Journal of Academic and Business Ethics, 12(4), 156-167.

Benestad, H. B. (2015). Scientific Communication. In Research in Medical and Biological Sciences: From Planning and Preparation to Grant Application and Publication. Berrett Koehler Inc. https://doi.org/10.1016/B9780-12-799943-2.00013-6

Bruton, S., \& Childers, D. (2016). The ethics and politics of policing plagiarism: a qualitative study of faculty views on student plagiarism and Turnitin ${ }^{\circledR}$. Assessment and Evaluation in Higher Education, 45(4), 134156.

https://doi.org/10.1080/026029 38.2015.1008981

Daryanto Setiawan. (2017). Perkembangan Teknologi Komunikasi Dan Dampaknya Terhadap Kehidupan. Jurnal Pendidikan, 2(2), 1-12. https://doi.org/10.1155/2015/1 46250

Hicks, A. (2011). "Mendeley": A Review. Collaborative Librarianship, 5(2), 34-56. https://doi.org/10.29087/2011. 3.2 .10

Kadir, K. (2017). Meta-Analysis Of The Effect Of Learning Intervention Toward Mathematical Thinking On Research And Publication Of Student. Tarbiya: Journal of
Education in Muslim Society, 3(1), 15-27. https://doi.org/10.15408/tjems. v4i2.8010

Knight, L., Hight, M., \& Polfer, L. (2010). Rethinking the library for the international student community. Reference Services Review, 5(2), 34-45. https://doi.org/10.1108/009073 21011090746

Melfianora. (2019). Penulisan Karya Tulis Ilmiah Dengan Studi Literatur. Open Science Framework, 12(1), 14-26.

Mohammadi, E., Thelwall, M., \& Kousha, K. (2016). Can Mendeley bookmarks reflect readership? A survey of user motivations. Journal of the Association for Information Science and Technology, 8(2), 66-74.

https://doi.org/10.1002/asi.234 77

Rahardja, U., Tiara, K., \& Rosalinda, I. A. (2016). Pemanfaatan Google Scholar Dan Citation Dalam Memenuhi Kebutuhan Pembuatan Skripsi Mahasiswa Pada Perguruan Tinggi. Technomedia Journal, 4(2), 16-26.

https://doi.org/10.33050/tmj.v1 i1.28

Wang, C., \& Blei, D. M. (2011). Collaborative topic modeling for recommending scientific articles. Proceedings of the ACM SIGKDD International Conference on Knowledge Discovery and Data Mining, 144-167.

https://doi.org/10.1145/202040 8.2020480 